\title{
Distribution of demersal fish in the south-western Barents Sea
}

\author{
Ingvar Byrkjedal' \& Åge Høines² \\ 1 Department of Natural History, Bergen Museum, University of Bergen, Muséplass 3, NO-5007 Bergen, Norway \\ 2 Institute of Marine Research, PO Box 1870 Nordnes, NO-5817 Bergen, Norway
}

\section{Keywords}

Biodiversity; Barents Sea; fish distribution; Polar Front.

\section{Correspondence \\ Ingvar Byrkjedal, Department of Natural History, Bergen Museum, University of Bergen, Muséplass 3, NO-5007 Bergen, Norway. \\ E-mail: ingvar.byrkjedal@zmb.uib.no}

doi:10.1111/j.1751-8369.2007.00030.x

\begin{abstract}
The composition of the demersal fish fauna of the Barents Sea, and the ranges of most of the fish species, have been relatively poorly known. From 257 bottom trawl hauls distributed in a uniform grid pattern over the southwestern part of the Barents Sea in summer 2000, all fish were identified. The sampled area included the Polar Front zone where warm Atlantic water meets cold (subzero) polar water. The material was used to map the distribution of the demersal fish species, and to analyse their distribution in relation to temperature, depth and salinity. Fifty-eight species were recorded. A fauna characterized by Gadidae and Scorpaenidae was found in the warmer part of the sea, whereas a cold-water fauna of mainly Cottidae, Zoarcidae and Stichaeidae was evident from the Polar Front zone and northwards. In logistic regression analyses temperature was the most important factor associated with the distribution of species (for 26 of the 27 species analysed), but associations with salinity ( 19 species) and depth ( 15 species) were also found. The mapping considerably revised the distribution in relation to previous knowledge for 37 species, and the new and more accurate range maps provided here may serve as baseline information for future monitoring of the fish fauna in the Barents Sea.
\end{abstract}

With its important fishing grounds, the Barents Sea is one of the well-researched areas of the oceans. However, the research on oceanography and fish stocks routinely carried out annually over many years, as well as special studies of parts of the ecosystem patterns and processes (see special issues of the journal Polar Research, volume 10, 1991, devoted to the "Pro Mare" project), have primarily been aimed at commercially valuable species (Fossheim et al. 2006). Far less effort has been made to study the biology and occurrence of species of no direct commercial importance, yet these constitute the majority of the species found in the area.

The main sources of knowledge about the fish fauna in the area have been regional faunas and surveys (Andriyashev 1964; Hognestad \& Vader 1979; Whitehead et al. 1984, 1986a, b; Pethon 2005), and data on the distribution of certain fish species have been given in connection with taxonomic revisions (Chernova 1988, 1998, 2005a, b; Chernova \& Borkin 1993). More recently, updates on newer observations have been published (Dolgov 2000, $2004,2006)$, and a classification of the fish assemblages has been made (Burgos 1989; Fossheim et al. 2006). In spite of this, an ichthyological biodiversity survey based on full-scale species identification has been lacking for this productive and important sea.

During the fishery cruises carried out by the Institute of Marine Reasearch (IMR), Bergen, in the south-western part of the Barents Sea in summer 2000, a special effort was made to identify all fish species caught in bottom trawls, in order to obtain more precise information on the distribution of demersal fish in the area. With its relatively shallow waters (mostly between 150 and $400 \mathrm{~m}$ in depth) and soft bottom substrates, the Barents Sea is topographically uniform, whereas bottom temperatures vary over short distances as the warmer Atlantic water meets the cold Arctic currents (Loeng 1991). A sharp gradient from above-zero to subzero temperatures is displayed along the Polar Front, which runs roughly diagonally from south-east to north-west across the area. Fossheim et al. (2006) indicated a change in the composition of the demersal fish fauna across the Polar Front in the Barents Sea. Sampling both sides of the Polar Front 
zone, the IMR cruises in summer 2000 yielded material suitable for analysis of fish distribution in relation to presumably the most important environmental variables in the area. Here we report the distribution of demersal species based on the material from these cruises, and analyse the distribution of species in relation to oceanographic variables.

\section{Material and methods}

The cruises were conducted with the research vessels Michael Sars and Johan Hjort from 20 July to 19 August 2000, comprising 257 valid bottom trawl hauls in the area roughly within $70-76^{\circ} \mathrm{N}$ and $16-40^{\circ} \mathrm{E}$ (Fig. 1). A Campelen 1800 shrimp trawl, with $40-\mathrm{m}$ sweeps and a cod-end equipped with a 22-mm mesh size inner lining, was used throughout the sampling period on both vessels. The trawl carried a rockhopper ground gear (Engås \& Godø 1989) and strapping was used to stabilize the opening of the trawl. Vaco trawl doors were employed $\left(6 \mathrm{~m}^{2}\right.$, $1500 \mathrm{~kg}$ ), and the trawl was equipped with Scanmar sensors that measured the distance between the doors, the vertical opening of the trawl and contact with the bottom. The standard trawling time was 30 min at 3 knots. At 23 stations, however, a towing time of $15 \mathrm{~min}$ was employed.

Species were identified on board as far as possible. Individuals that posed identification problems were frozen and subsequently transferred to the Bergen Museum for taxonomic examination against specimens in the museum collections. Moreover, voucher specimens were taken to

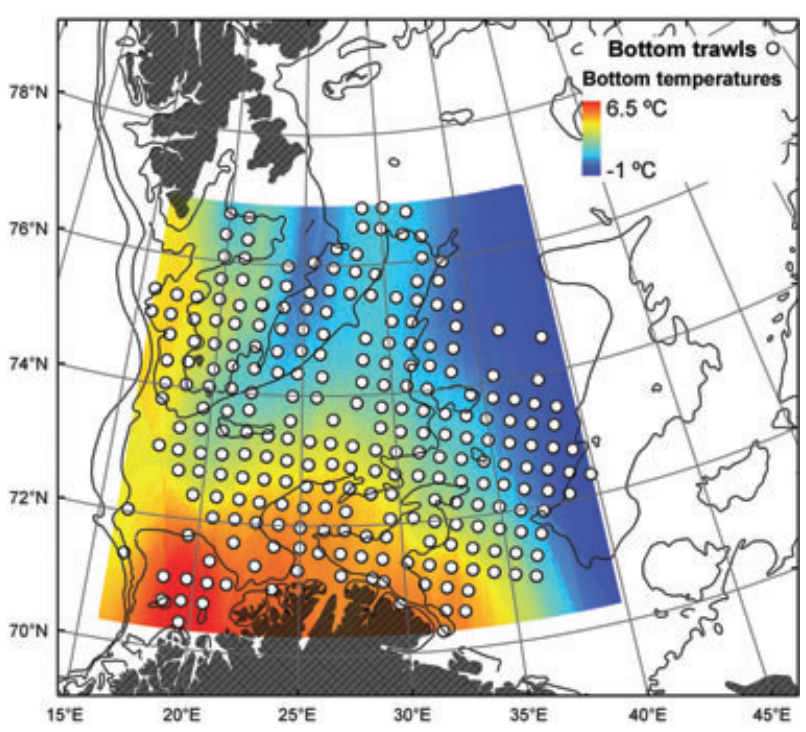

Fig. 1 Distribution of the bottom trawl stations in the western Barents Sea, summer 2000. the museum for preservation and permanent storage. The main identification keys used were those of Andriyashev (1964), Whitehead et al. (1984, 1986a, b) and Pethon (1998), but special publications on Liparidae and Zoarcidae (Chernova 1988, 1991, 1998, 2005a, b) became available and were consulted after the cruise.

We analysed the occurrence of the various species in relation to average station gear depth, and to temperature and salinity measured by a conductivity-temperaturedepth recorder (CTD) 8-10 $\mathrm{m}$ above the bottom immediately before the start of each trawl station. Many of the species had very high catches on single stations, causing a high degree of heteroscedacity. This bias can be handled with multivariate logistic regressions, which was therefore chosen. The analyses were performed (in SPSS 13.0) with a backward stepwise model building.

We examined the independent variables (temperature, salinity and depth) for multicollinearity by computing the variance inflation factor (VIF) for each variable, as the reciprocal of $1-R^{2}$ for the regression of each variable on both of the others. A VIF value of 4.0 or higher is customarily used as a criterion to suggest a multicollinearity problem. The VIF values for temperature, salinity and depth $(1.804,1.001$ and 1.010 , respectively) were far below the critical value.

To avoid overfit tea models, i.e. models in which significant relationships could occur due to noise, we employed a $10: 1$ ratio of data points of interest in relation to number of variables. Following this, only species with positive records at 30 or more stations were analysed, with the exception of Icelus bicornis, of which the 27 positive records was close to a $10: 1$ ratio.

We excluded the following pelagic species: Mallotus villosus, Maurolicus muelleri, Clupea harengus, Nansenia groenlandica, Argenitna silus, Boreogadus saida and Arctozenus risso, but included gadoid species that can be classified as pelagic, but spend much of the time close to the bottom: Gadus morhua, Pollachius spp., Micromesistius poutassou, Trisopterus esmarkii and Gadiculus argenteus.

\section{Results}

Altogether 58 demersal fish species were represented in the material (Table 1). Of these, eight species were distributed over practically the whole sampling area G. morhua, Melanogrammus aeglefinus, Sebastes marinus, Artediellus atlanticus, Careproctus derjugini, Anarhichas lupus, A. minor and Hippoglossoides platessoides (Fig. 2), whereas the other species were confined chiefly to either the southern and western waters influenced by the Atlantic current, or to the cold waters in the north and east near the Polar Front. In the south and west, 11 species showed a wide distribution extending well into the Bear Island 
Table 1 Bottom fish caught on 257 trawl stations in the western Barents Sea in the summer of 2000.

\begin{tabular}{|c|c|c|c|c|c|c|}
\hline Taxon & $N$ individuals & N stations & $\begin{array}{l}\% \text { of } \\
\text { individuals }\end{array}$ & $\begin{array}{l}\% \text { of } \\
\text { stations }\end{array}$ & $\begin{array}{l}\text { Voucher } \\
\text { specimens: } \\
N \text { individuals }\end{array}$ & $\begin{array}{l}\text { Voucher } \\
\text { specimens: } \\
N \text { lots }\end{array}$ \\
\hline \multicolumn{7}{|l|}{ MYXINIDAE } \\
\hline Myxine glutinosa Linnaeus, 1758 & 2 & 1 & + & 0.4 & & \\
\hline \multicolumn{7}{|l|}{ CHIMAERIDAE } \\
\hline Chimaera monstrosa Linnaeus, 1758 & 4 & 2 & + & 0.8 & 1 & 1 \\
\hline \multicolumn{7}{|l|}{ RAJIDAE } \\
\hline Amblyraja hyperborea (Collett, 1879) & 24 & 8 & + & 3.1 & & \\
\hline Amblyraja radiata (Donovan, 1808) & 1039 & 168 & 0.4 & 65.4 & 4 & 3 \\
\hline Bathyraja spinicauda (Jensen, 1914) & 12 & 10 & + & 3.9 & & \\
\hline Dipturus batis (Linnaeus, 1758) & 2 & 2 & + & 0.8 & & \\
\hline Dipturus linteus (Fries, 1838) & 1 & 1 & + & 0.4 & 1 & 1 \\
\hline Raja clavata Linnaeus, 1758 & 5 & 1 & + & 0.4 & & \\
\hline Rajella fyllae (Lütken, 1887) & 31 & 23 & 0.1 & 14.4 & 10 & 10 \\
\hline \multicolumn{7}{|l|}{ MACROURIDAE } \\
\hline Macrourus berglax Lacepède, 1801 & 12 & 5 & + & 1.9 & & \\
\hline \multicolumn{7}{|l|}{ PHYCIDAE } \\
\hline Phycis blennoides (Brünnich, 1768) & 1 & 1 & + & 0.4 & & \\
\hline \multicolumn{7}{|l|}{ GADIDAE: GADINAE } \\
\hline Gadiculus argenteus thori Schmidt, 1914 & 127 & 19 & 0.1 & 7.4 & & \\
\hline Gadus morhua Linnaeus, 1758 & 31047 & 245 & 12.9 & 95.3 & & \\
\hline Melanogrammus aeglefinus (Linnaeus, 1758) & 28578 & 202 & 11.9 & 78.6 & 6 & 1 \\
\hline Micromesistius poutassou (Risso, 1827) & 68055 & 94 & 28.3 & 36.6 & & \\
\hline Pollachius pollachius (Linnaeus, 1758) & 1 & 1 & + & 0.4 & & \\
\hline Pollachius virens (Linnaeus, 1758) & 357 & 37 & 0.1 & 14.4 & & \\
\hline Trisopterus esmarkii (Nilsson, 1855) & 6398 & 55 & 2.7 & 21.4 & & \\
\hline \multicolumn{7}{|l|}{ GADIDAE: LOTINAE } \\
\hline Brosme brosme Ascanius, 1772 & 84 & 18 & + & 7.0 & 4 & 2 \\
\hline Molva molva (Linnaeus, 1758) & 4 & 2 & + & 0.8 & & \\
\hline Molva dypterygia (Pennant, 1784) & 6 & 1 & + & 0.4 & & \\
\hline Enchelyopus cimbrius (Linnaeus, 1766) & 35 & 21 & + & 8.2 & 2 & 2 \\
\hline Gaidropsarus argentatus (Reinhardt, 1837) & 1 & 1 & + & 0.4 & 1 & 1 \\
\hline \multicolumn{7}{|l|}{ SCORPAENIDAE } \\
\hline Sebastes marinus (Linnaeus, 1758) & 2005 & 89 & 0.8 & 34.6 & 2 & 2 \\
\hline Sebastes mentella (Travin, 1951) & 18454 & 136 & 7.7 & 52.9 & 15 & 4 \\
\hline Sebastes viviparus Krøyer, 1845 & 560 & 30 & 0.2 & 11.7 & & \\
\hline \multicolumn{7}{|l|}{ COTTIDAE } \\
\hline Artediellus atlanticus Jordan \& Evermann, 1898 & 4840 & 174 & 2.0 & 67.7 & 144 & 47 \\
\hline Gymnocanthus tricuspis (Reinhardt, 1830) & 96 & 11 & + & 4.3 & 43 & 13 \\
\hline Icelus bicornis (Reinhardt, 1840) & 200 & 27 & 0.1 & 10.5 & 24 & 15 \\
\hline Icelus spatula Gilbert \& Burke, 1812 & 50 & 10 & + & 3.9 & 26 & 7 \\
\hline Myoxocephalus scorpius (Linnaeus, 1758) & 16 & 7 & + & 2.7 & 11 & 7 \\
\hline Triglops murrayi Günther, 1888 & 5715 & 93 & 2.4 & 36.2 & 387 & 57 \\
\hline Triglops nybelini Jensen, 1944 & 1017 & 27 & 0.4 & 10.5 & 51 & 22 \\
\hline Triglops pingeli Reinhardt, 1837 & 975 & 26 & 0.4 & 10.1 & 57 & 17 \\
\hline \multicolumn{7}{|l|}{ AGONIDAE } \\
\hline Leptagonus decagonus (Bloch \& Schneider, 1801) & 3130 & 103 & 1.3 & 40.1 & 45 & 20 \\
\hline \multicolumn{7}{|l|}{ PSYCHROLUTIDAE } \\
\hline Cottunculus microps Collett, 1875 & 111 & 60 & + & 23.3 & 22 & 14 \\
\hline \multicolumn{7}{|l|}{ CYCLOPTERIDAE } \\
\hline Eumicrotremus spinosus (Fabricius, 1776) & 117 & 22 & + & 8.6 & 49 & 22 \\
\hline \multicolumn{7}{|l|}{ LIPARIDAE } \\
\hline Careproctus derjugini Chernova, 2005 & 697 & 130 & 0.3 & 50.6 & 166 & 82 \\
\hline Careproctus dubius Zugmayer, 1911 & 18 & 9 & + & 3.5 & 12 & 9 \\
\hline Liparis fabricii Krøyer, 1847 & 20 & 7 & + & 2.7 & 6 & 6 \\
\hline Liparis gibbus Bean, 1881 & 102 & 15 & + & 5.8 & 18 & 10 \\
\hline
\end{tabular}


Table 1 Continued

\begin{tabular}{|c|c|c|c|c|c|c|}
\hline Taxon & $N$ individuals & N stations & $\begin{array}{l}\% \text { of } \\
\text { individuals }\end{array}$ & $\begin{array}{l}\% \text { of } \\
\text { stations }\end{array}$ & $\begin{array}{l}\text { Voucher } \\
\text { specimens: } \\
N \text { individuals }\end{array}$ & $\begin{array}{l}\text { Voucher } \\
\text { specimens: } \\
N \text { lots }\end{array}$ \\
\hline \multicolumn{7}{|l|}{ ZOARCIDAE } \\
\hline Gymnelus retrodorsalis Le Danois, 1913 & 120 & 18 & + & 7.0 & 31 & 15 \\
\hline Lycenchelys kolthoffi Jensen, 1904 & 19 & 2 & + & 0.8 & 17 & 2 \\
\hline Lycodes esmarkii Collett, 1875 & 28 & 11 & + & 4.3 & 1 & 1 \\
\hline Lycodes eudipleurostictus Jensen, 1902 & 83 & 19 & + & 7.4 & 32 & 16 \\
\hline Lycodes gracilis M. Sars, 1867 & 2785 & 141 & 1.2 & 54.9 & 102 & 38 \\
\hline Lycodes pallidus Collett, 1879 & 101 & 17 & + & 6.6 & 23 & 11 \\
\hline Lycodes reticulatus Reinhardt, 1835 & 261 & 36 & 0.1 & 14.0 & 32 & 22 \\
\hline Lycodes rossi Malmgren, 1865 & 686 & 69 & 0.3 & 26.8 & 128 & 54 \\
\hline Lycodes seminudus Reinhardt, 1837 & 214 & 18 & 0.1 & 7.0 & 32 & 16 \\
\hline Lycodes squamiventer Jensen, 1904 & 3 & 3 & + & 1.2 & 1 & 1 \\
\hline \multicolumn{7}{|l|}{ STICHAEIDAE } \\
\hline Lumpenus lampretaeformis (Walbaum, 1792) & 2826 & 102 & 1.2 & 39.7 & 205 & 63 \\
\hline Leptoclinus maculatus (Fries, 1837) & 4686 & 121 & 2.0 & 47.1 & 213 & 53 \\
\hline \multicolumn{7}{|l|}{ ANARHICHADIDAE } \\
\hline Anarhichas denticulatus Krøyer, 1845 & 248 & 102 & 0.1 & 39.7 & 1 & 1 \\
\hline Anarhichas lupus Linnaeus, 1758 & 273 & 42 & 0.1 & 16.3 & 10 & 7 \\
\hline Anarhichas minor Olafsen, 1772 & 385 & 79 & 0.2 & 37.7 & 22 & 14 \\
\hline \multicolumn{7}{|l|}{ AMMODYTIDAE } \\
\hline Ammodytes marinus Raitt, 1934 & 2 & 1 & + & 0.4 & & \\
\hline \multicolumn{7}{|l|}{ PLEURONECTIDAE } \\
\hline Hippoglossus hippoglossus (Linnaeus, 1758) & 1 & 1 & + & 0.4 & & \\
\hline Reinhardtius hippoglossoides (Walbaum, 1792) & 624 & 90 & 0.3 & 35.0 & & \\
\hline Hippoglossoides platessoides (Fabricius, 1780) & 52909 & 248 & 22.0 & 96.5 & 6 & 4 \\
\hline Glyptocephalus cynoglossus (Linnaeus, 1758) & 5 & 2 & + & 0.8 & 1 & 1 \\
\hline Microstomus kitt (Walbaum, 1792) & 25 & 5 & + & 1.9 & 2 & 2 \\
\hline Pleuronectes platessa Linnaeus, 1758 & 6 & 3 & + & 1.2 & & \\
\hline
\end{tabular}

Percentages $<0.1 \%$ denoted by + .

Trough (Fig. 3): Amblyraja radiata, Bathyraja spinicauda, Micromesistius poutassou, Pollachius virens, Sebastes mentella, Cottunculus microps, Lycodes esmarkii, L. eudipleurostictus, L. gracilis, Reinhardtius hippoglossoides and, to some extent, Macrourus berglax. No less than 17 species were confined to the warmer coastal current along the mainland (Fig. 4): Myxine glutinosa, Chimaera monstrosa, Rajella fyllae, Dipturus batis, D. linteus, Gadiculus argenteus, Trisopterus esmarkii, Pollachius pollachius, Molva molva, M. dypterygia, Gaidropsarus argentatus, Phycis blennoides, Sebastes viviparus, Microstomus kitt, Hippoglossus hippoglossus, Pleuronectes platessa and Glyptocephalus cynoglossus. In spite of the few records north-west of Bjørnøya (Bear Island), two more species could be assigned to this category: Brosme brosme and Enchelyopus cimbrius. Being on the border of their range, several of the species from the coastal current zone were represented only by a single or a few individuals (M. glutinosa, C. monstrosa, D. batis, D. linteus, P. blennoides, G. argentatus, M. molva, M.dypterygia, H. hippoglossus and G. cynoglossus; see Table 1).

Species mainly distributed from the Polar Front northwards (Fig. 5) were Amblyraja hyperborea, Gymnocanthus tricuspis, Myoxocephalus scorpius, Icelus bicornis, I. spatula, Triglops murrayi, T. nybelini, T. pingeli, Leptagonus decagonus, Eumicrotremus spinosus, Careproctus dubius, Liparis fabricii, L.gibbus, Gymnelus retrodorsalis, Lycenchelys kolthoffi, L. pallidus, L. reticulatus, L. rossi, L. seminudus, Lumpenus lampretaeformis, Leptoclinus maculatus and Anarhichas denticulatus. Of these, three species were confined to the Bear Island Bank: G. tricuspis, M. scorpius and E. spinosus.

Of the 27 species numerous enough for analysis, none showed a random distribution in relation to the three factors (bottom temperature, depth and salinity) entered in a logistic regression analysis (Table 2): all the species showed a significant relationship to at least one of the factors, 15 species to two factors and nine species to all three factors. All but one of the 27 species showed a distribution related to temperature, whereas a relation to depth was found for 19 , and to salinity for 15 of the species.

Of the 14 species associating with cold water, $A$.denticulatus, C.derjugini and R.hippoglossoides also associated with deeper water, and T.pingeli, T. murrayi, T. nybelini, A. atlanticus, Leptoclinus maculatus, Lumpenus 

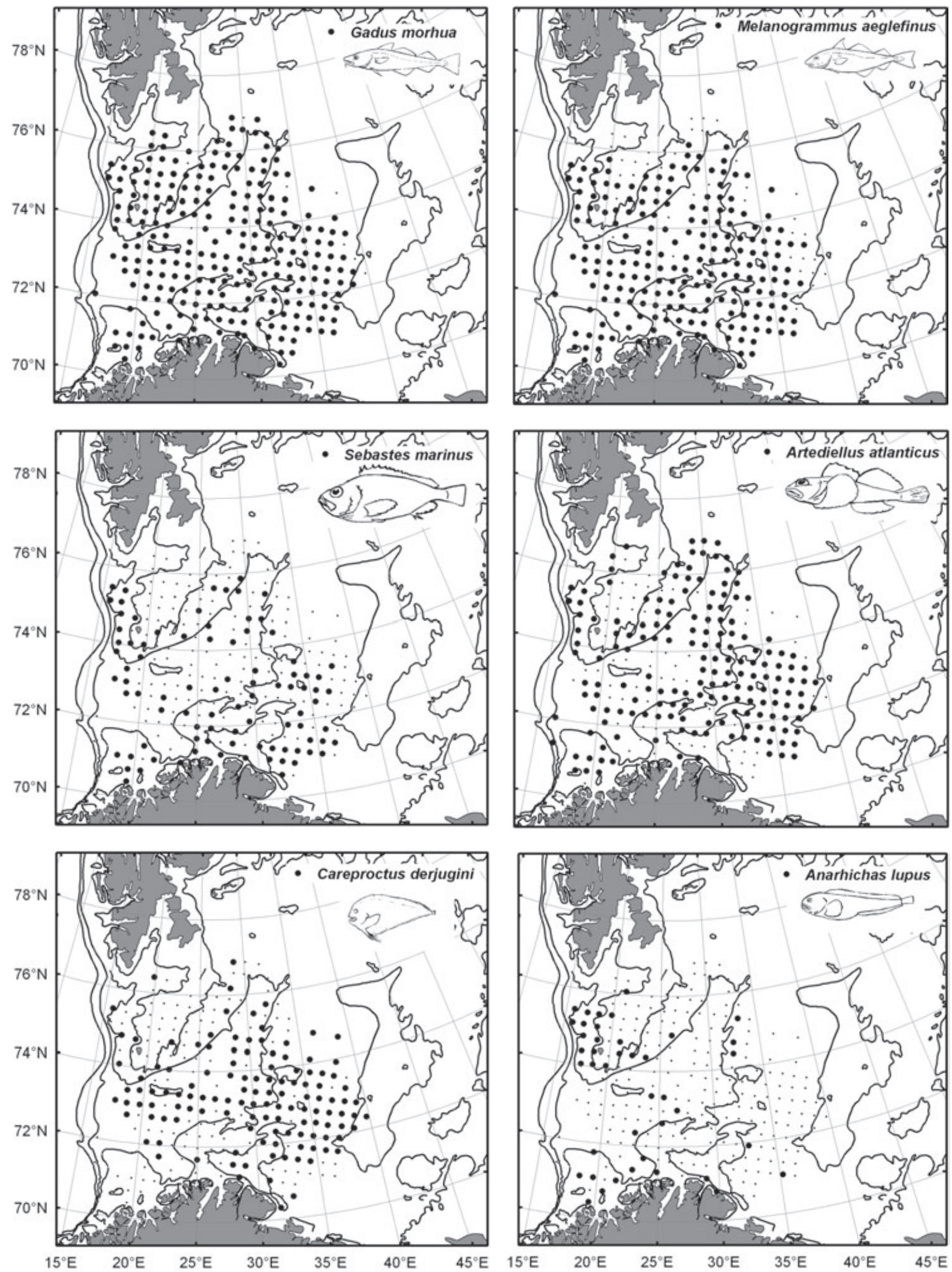

Fig. 2 Fish species with a wide distribution in the area sampled. Large dots and small dots indicate trawl stations with positive and negative registrations, respectively. 

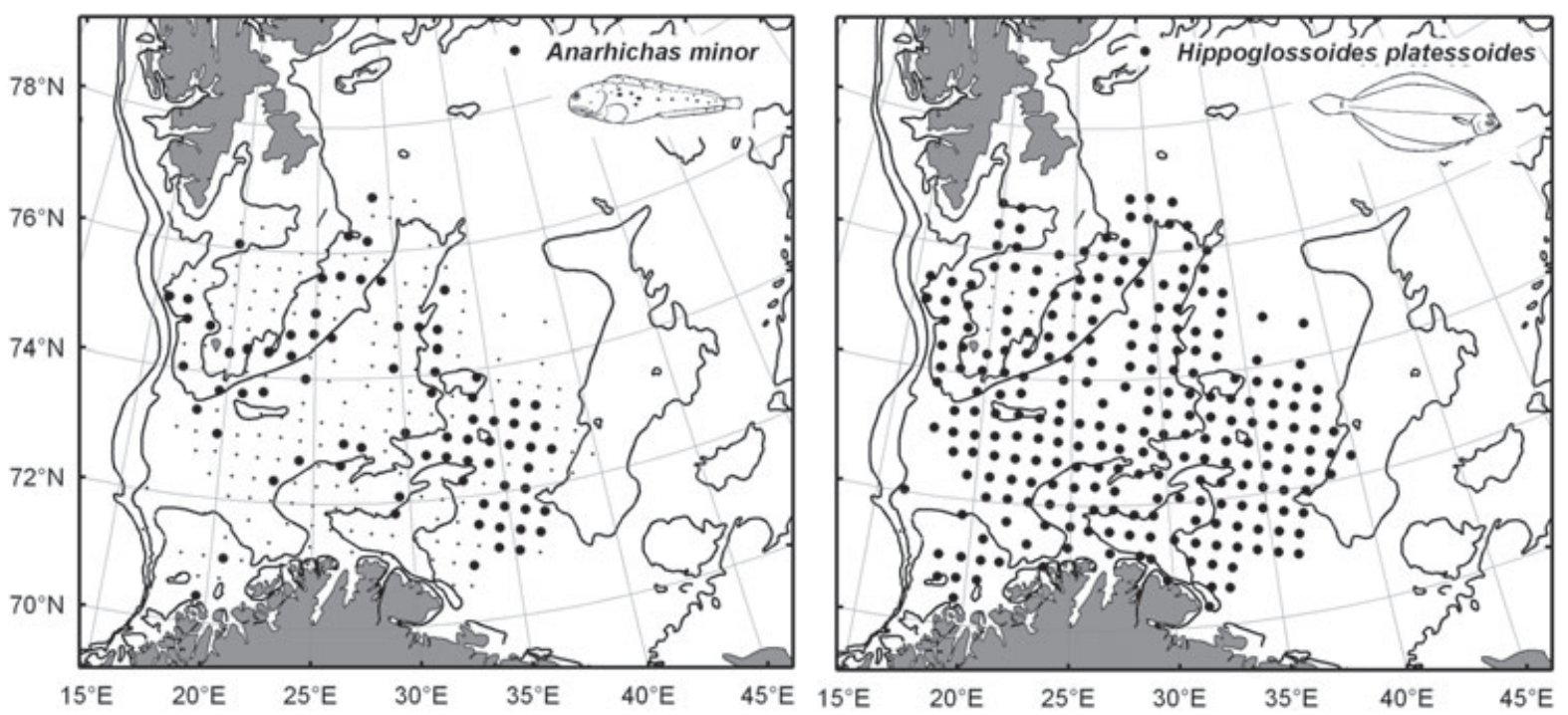

Fig. 2 Continued

Table 2 Occurrence of fish in relation to environmental variables, as shown by remaining variables in backwards stepwise logistic regression models.

\begin{tabular}{|c|c|c|c|c|}
\hline Species & Test parameters & Temperature & Depth & Salinity \\
\hline \multirow[t]{3}{*}{ Amblyraja radiata } & $B$ & 0.180 & 0.007 & \\
\hline & Wald $\chi 2$ & 5.234 & 23.167 & \\
\hline & $p$ & 0.022 & $<0.001$ & \\
\hline \multirow[t]{3}{*}{ Gadus morhua } & $B$ & 2.067 & -0.011 & \\
\hline & Wald $\chi 2$ & 15.415 & 6.235 & \\
\hline & $p$ & $<0.001$ & 0.013 & \\
\hline \multirow[t]{3}{*}{ Melanogrammus aeglefinus } & $B$ & 0.909 & -0.006 & 6.965 \\
\hline & Wald $\chi 2$ & 32.732 & 6.636 & 20.295 \\
\hline & $p$ & $<0.001$ & 0.010 & $<0.001$ \\
\hline \multirow[t]{3}{*}{ Micromesistius poutassou } & $B$ & 1.205 & 0.024 & \\
\hline & Wald $\chi 2$ & 48.318 & 44.308 & \\
\hline & $p$ & $<0.001$ & $<0.001$ & \\
\hline \multirow[t]{3}{*}{ Pollachius virens } & $B$ & 1.123 & & \\
\hline & Wald $\chi 2$ & 34.003 & & \\
\hline & $p$ & $<0.001$ & & \\
\hline \multirow[t]{3}{*}{ Trisopterus esmarkii } & $B$ & 1.046 & & \\
\hline & Wald $\chi 2$ & 44.861 & & \\
\hline & $p$ & $<0.001$ & & \\
\hline \multirow[t]{3}{*}{ Sebastes marinus } & $B$ & 0.351 & -0.007 & 7.844 \\
\hline & Wald $\chi 2$ & 15.453 & 10.278 & 13.379 \\
\hline & $p$ & $<0.001$ & $<0.001$ & $<0.001$ \\
\hline \multirow[t]{3}{*}{ Sebastes mentella } & $B$ & 0.594 & 0.030 & \\
\hline & Wald $\chi 2$ & 28.691 & 49.101 & \\
\hline & $p$ & $<0.001$ & $<0.001$ & \\
\hline \multirow[t]{3}{*}{ Sebastes viviparus } & $B$ & 1.738 & 0.010 & \\
\hline & Wald $\chi 2$ & 24.824 & 5.217 & \\
\hline & $p$ & $<0.001$ & 0.022 & \\
\hline \multirow[t]{3}{*}{ Artediellus atlanticus } & $B$ & -0.333 & -0.007 & 9.468 \\
\hline & Wald $\chi 2$ & 12.857 & 13.582 & 24.703 \\
\hline & $p$ & $<0.001$ & $<0.001$ & $<0.001$ \\
\hline
\end{tabular}


Table 2 Continued

\begin{tabular}{|c|c|c|c|c|}
\hline Species & Test parameters & Temperature & Depth & Salinity \\
\hline \multirow[t]{3}{*}{ Icelus bicornis } & $B$ & -1.293 & & -5.484 \\
\hline & Wald $\chi 2$ & 27.655 & & 17.453 \\
\hline & $p$ & $<0.001$ & & $<0.001$ \\
\hline \multirow[t]{3}{*}{ Triglops murrayi } & $B$ & -0.486 & -0.018 & 5.379 \\
\hline & Wald $\chi 2$ & 27.722 & 36.867 & 15.686 \\
\hline & $p$ & $<0.001$ & $<0.001$ & $<0.001$ \\
\hline \multirow[t]{3}{*}{ Triglops nybelini } & $B$ & -1.149 & -0.016 & 15.995 \\
\hline & Wald $\chi 2$ & 17.725 & 10.497 & 6.550 \\
\hline & $p$ & $<0.001$ & 0.001 & 0.010 \\
\hline \multirow[t]{3}{*}{ Triglops pingeli } & $B$ & -0.983 & -0.009 & \\
\hline & Wald $\chi 2$ & 23.822 & 8.849 & \\
\hline & $p$ & $<0.001$ & 0.003 & \\
\hline \multirow[t]{3}{*}{ Leptagonus decagonus } & $B$ & -1.927 & & 12.997 \\
\hline & Wald $\chi 2$ & 56.186 & & 14.906 \\
\hline & $p$ & $<0.001$ & & $<0.001$ \\
\hline \multirow[t]{3}{*}{ Cottunculus microps } & $B$ & 0.337 & 0.006 & \\
\hline & Wald $\chi 2$ & 12.431 & 11.944 & \\
\hline & $p$ & $<0.001$ & 0.001 & \\
\hline \multirow[t]{3}{*}{ Careproctus derjugini } & $B$ & -0.415 & 0.009 & \\
\hline & Wald $\chi 2$ & 23.254 & 29.381 & \\
\hline & $p$ & $<0.001$ & $<0.001$ & \\
\hline \multirow[t]{3}{*}{ Lycodes gracilis } & $B$ & 0.626 & & 12.979 \\
\hline & Wald $\chi 2$ & 29.671 & & 16.584 \\
\hline & $p$ & $<0.001$ & & $<0.001$ \\
\hline \multirow[t]{3}{*}{ Lycodes reticulatus } & B & -1.362 & & 7.075 \\
\hline & Wald $\chi 2$ & 25.322 & & 4.278 \\
\hline & $p$ & $<0.001$ & & 0.039 \\
\hline \multirow[t]{3}{*}{ Lycodes rossi } & $B$ & -2.599 & & 32.431 \\
\hline & Wald $\chi 2$ & 35.053 & & 14.607 \\
\hline & $p$ & $<0.001$ & & $<0.001$ \\
\hline \multirow[t]{3}{*}{ Lumpenus lampretaeformis } & $B$ & -0.367 & -0.018 & 10.679 \\
\hline & Wald $\chi 2$ & 17.428 & 40.797 & 27.052 \\
\hline & $p$ & $<0.001$ & $<0.001$ & $<0.001$ \\
\hline \multirow[t]{3}{*}{ Leptoclinus maculatus } & $B$ & -1.024 & -0.017 & 7.224 \\
\hline & Wald $\chi 2$ & 66.696 & 34.466 & 20.732 \\
\hline & $P$ & $<0.001$ & $<0.001$ & $<0.001$ \\
\hline \multirow[t]{3}{*}{ Anarhichas denticulatus } & $B$ & -0.283 & 0.005 & \\
\hline & Wald $\chi 2$ & 9.578 & 6.995 & \\
\hline & $P$ & 0.002 & 0.008 & \\
\hline \multirow[t]{3}{*}{ Anarhichas lupus } & $B$ & 0.495 & -0.015 & 4.486 \\
\hline & Wald $\chi 2$ & 18.582 & 17.915 & 7.689 \\
\hline & $p$ & $<0.001$ & $<0.001$ & 0.006 \\
\hline \multirow[t]{3}{*}{ Anarhichas minor } & $B$ & -0.223 & -0.009 & 5.944 \\
\hline & Wald $\chi 2$ & 7.367 & 16.125 & 12.453 \\
\hline & $P$ & 0.007 & $<0.001$ & $<0.001$ \\
\hline \multirow[t]{3}{*}{ Reinhardtius hippoglossoides } & $B$ & -0.416 & 0.025 & \\
\hline & Wald $\chi 2$ & 13.651 & 55.329 & \\
\hline & $P$ & $<0.001$ & $<0.001$ & \\
\hline \multirow[t]{3}{*}{ Hippoglossoides platessoides } & $B$ & & & 5.421 \\
\hline & Wald $\chi 2$ & & & 23.993 \\
\hline & $P$ & & & $<0.001$ \\
\hline
\end{tabular}



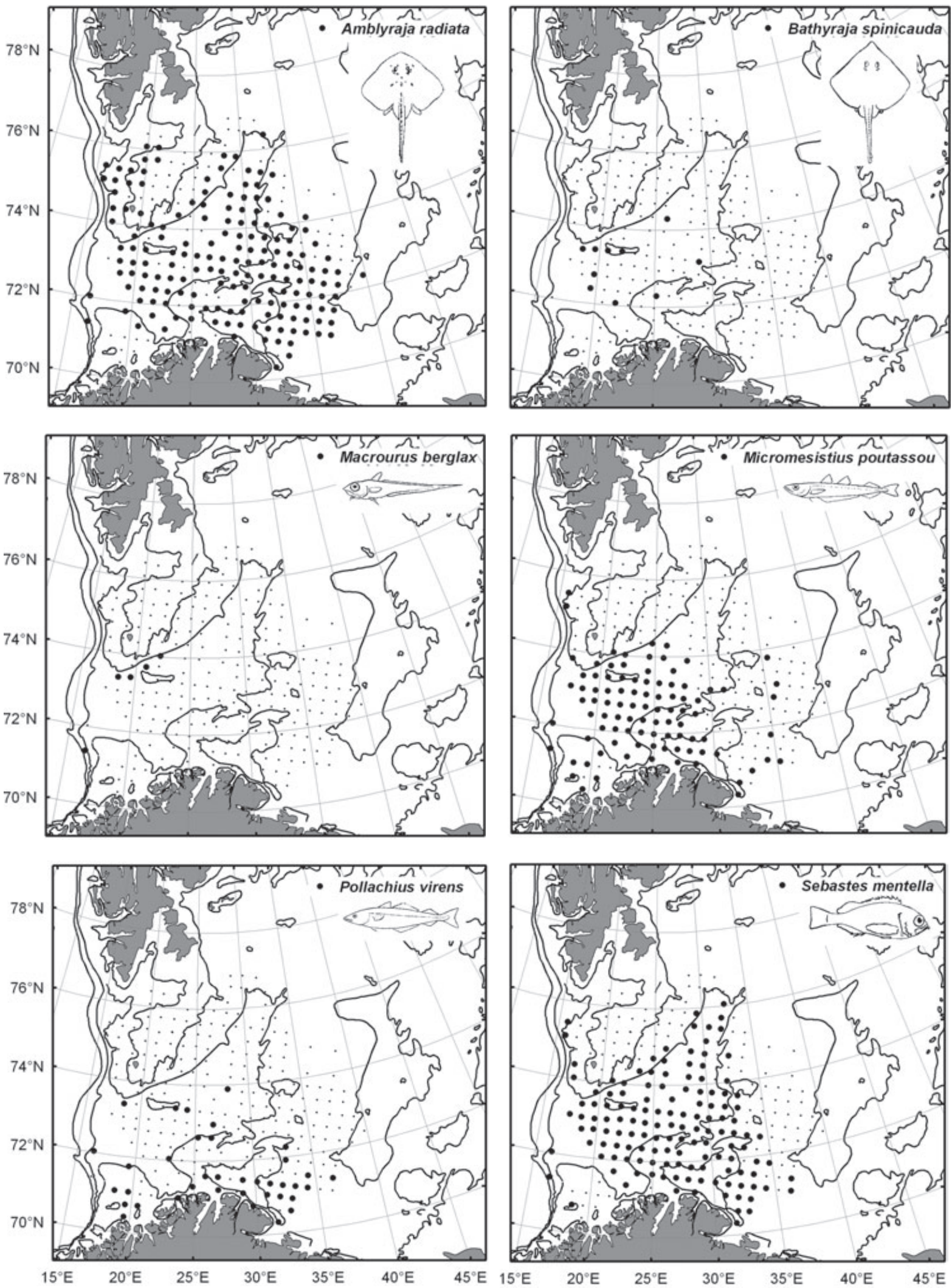

Fig. 3 Fish species with a wide distribution in the western part of the Barents Sea, strongly influenced by Atlantic water. Large dots and small dots indicate trawl stations with positive and negative registrations, respectively. 

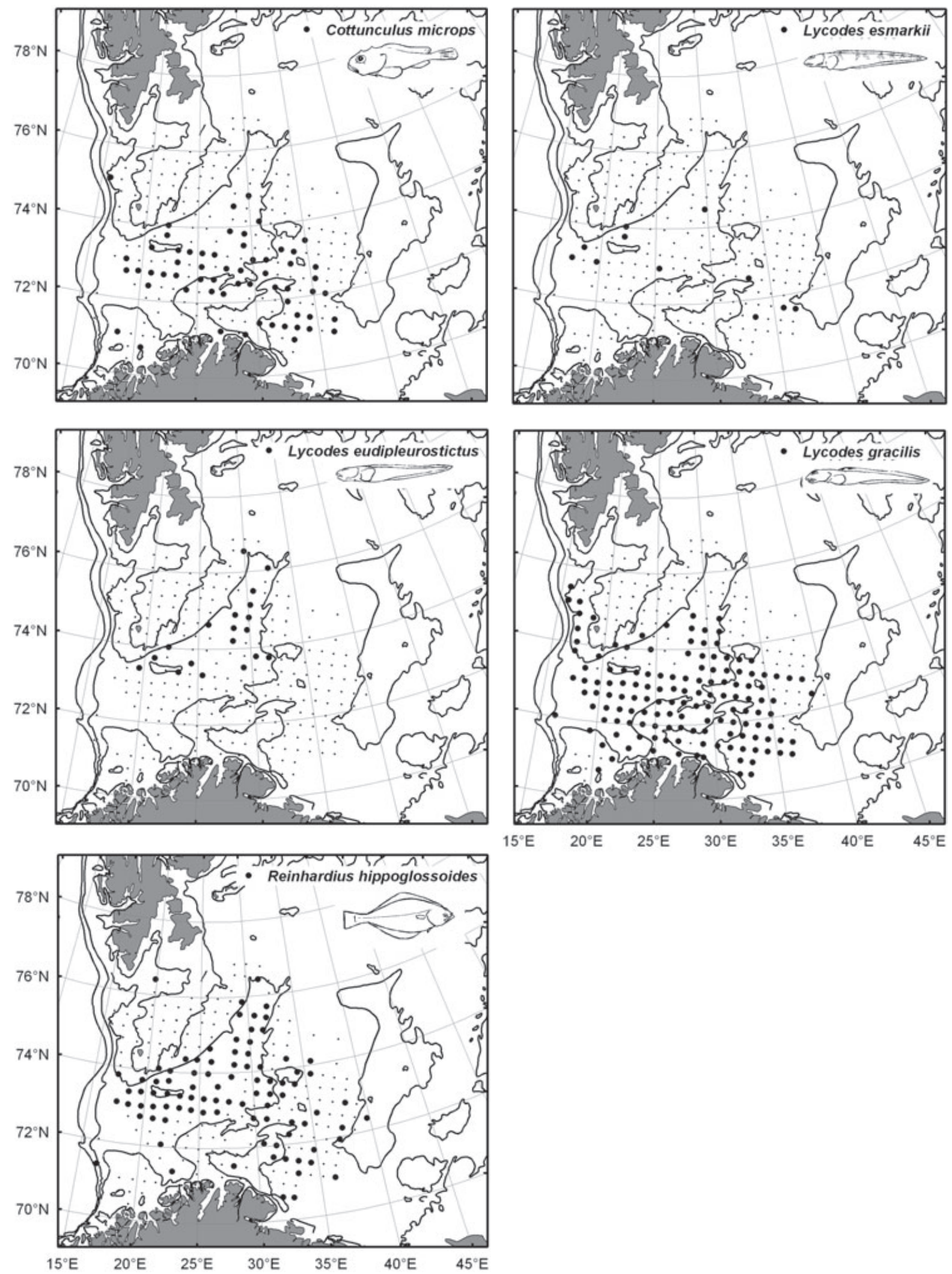

Fig. 3 Continued 

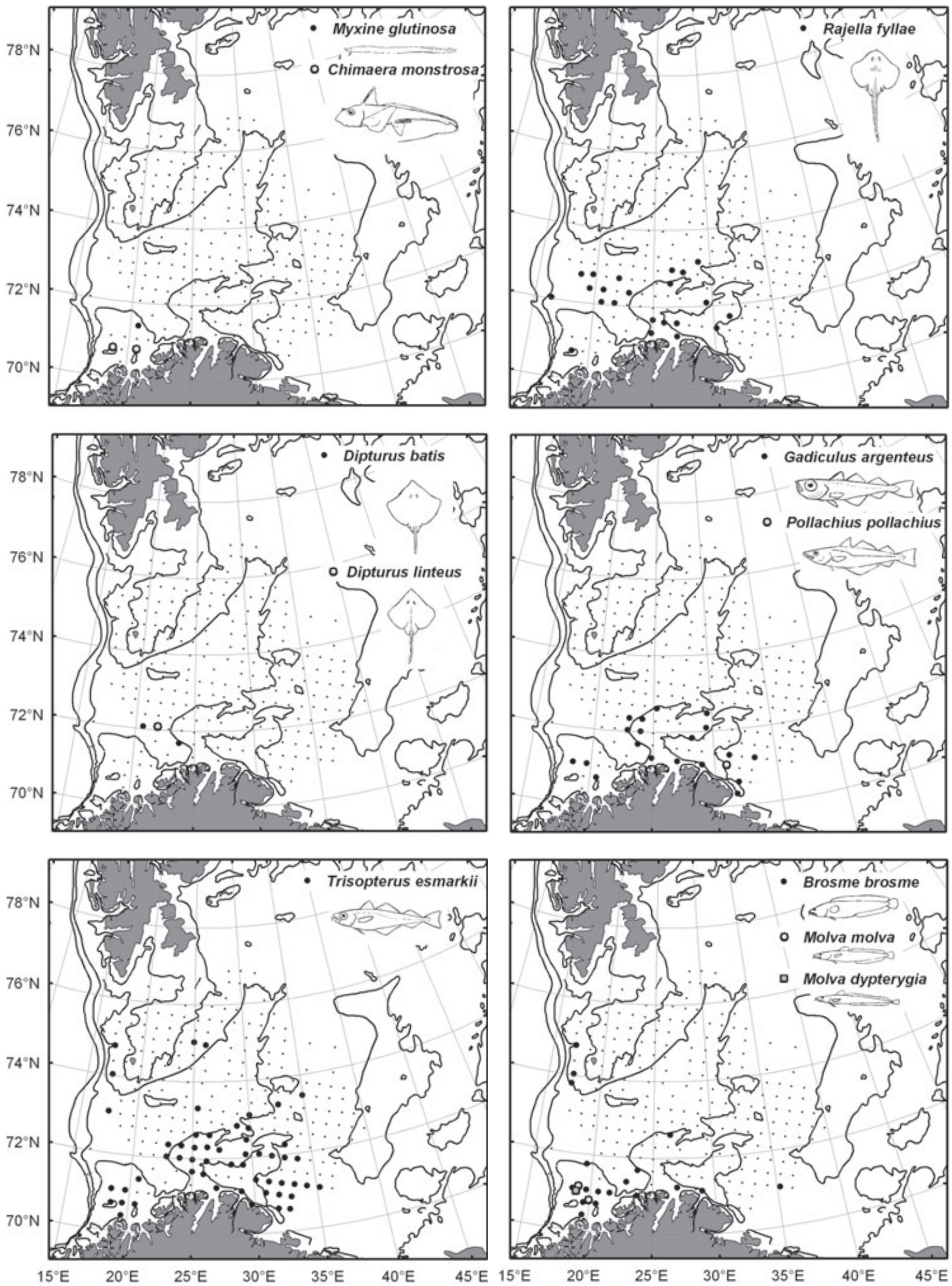

Fig. 4 Fish species found mainly in coastal current waters along the mainland. Large dots, circles and squares indicate trawl stations with positive registrations. Small dots indicate trawl stations with negative registrations. 

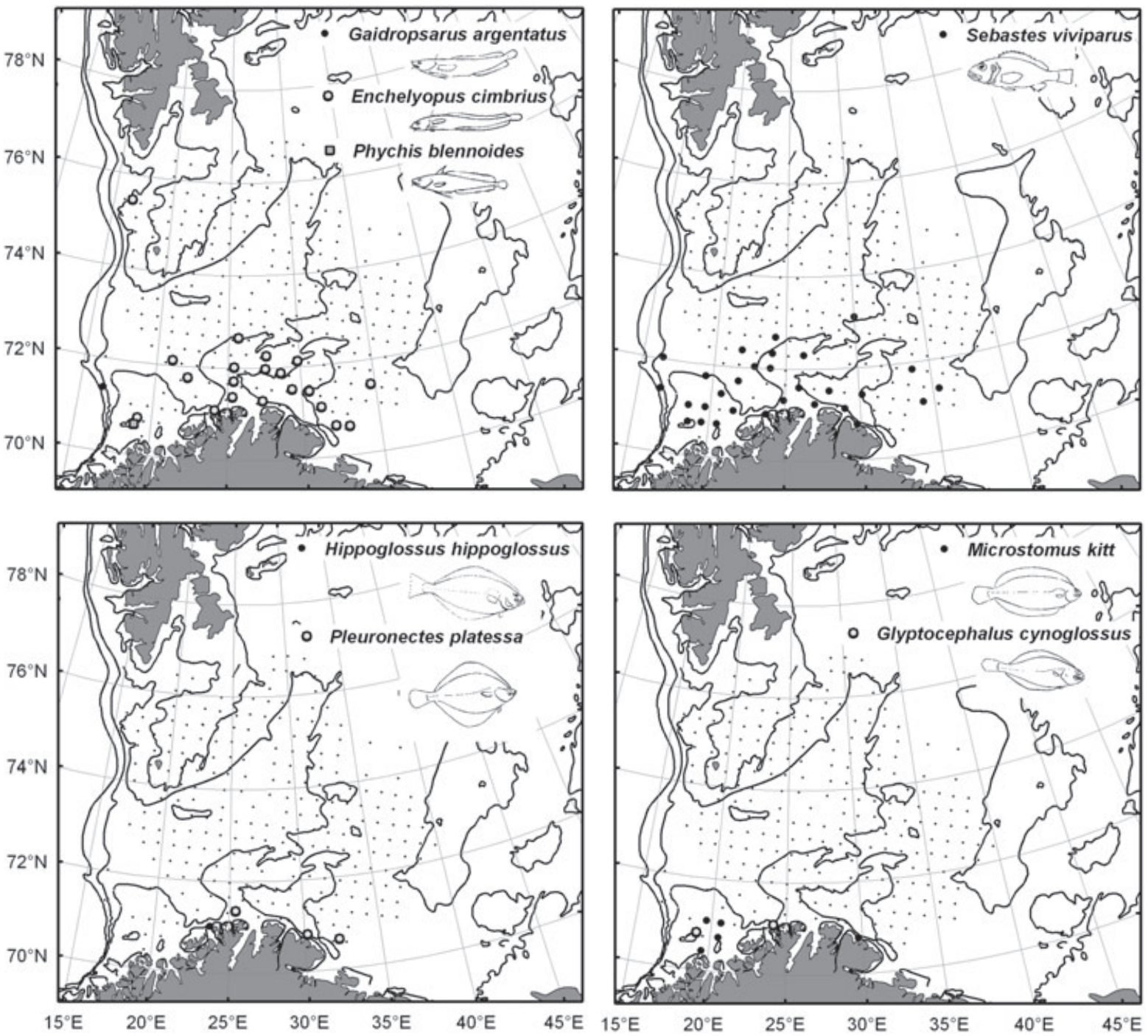

Fig. 4 Continued

lampretaeformis and A.minor associated with shallower water, the latter six species associating with higher salinity as a third variable. Three of the cold water species, Leptagonus decagonus, Lycodes reticulatus and L. rossi, associated with higher salinity as a second variable, and finally I. bicornis associated with lower salinity in addition to cold water.

Two of the 12 species associating with higher water temperatures, P. virens and T. esmarkii, showed no significant relationship to depth or salinity, whereas $A$. radiata, M. poutassou, S. mentella, S. viviparus and C. microps associated with deeper water in addition to higher temperatures. Four species with affinity to warmer water, G. morhua, M. aeglefinus, S. marinus and A. lupus associated with shallower water, and the three latter species also associated with higher salinity. L. gracilis associated with higher temperatures and salinity, whereas H. platessoides associated with higher salinity as a sole factor.

\section{Discussion}

The present study was based on a single cruise from one year only. This might limit the general conclusions that can be drawn from the material, especially regarding the distribution of more mobile species. On the other hand, this concentrated sampling facilitates comparability of the sampling stations, and thereby analysis. On account of this, combined with the dense grid sampling applied, the present study offers more precise distributional information for the species of which range maps have been based on more or less unspecified information, both regarding time periods and sampling methodologies. 

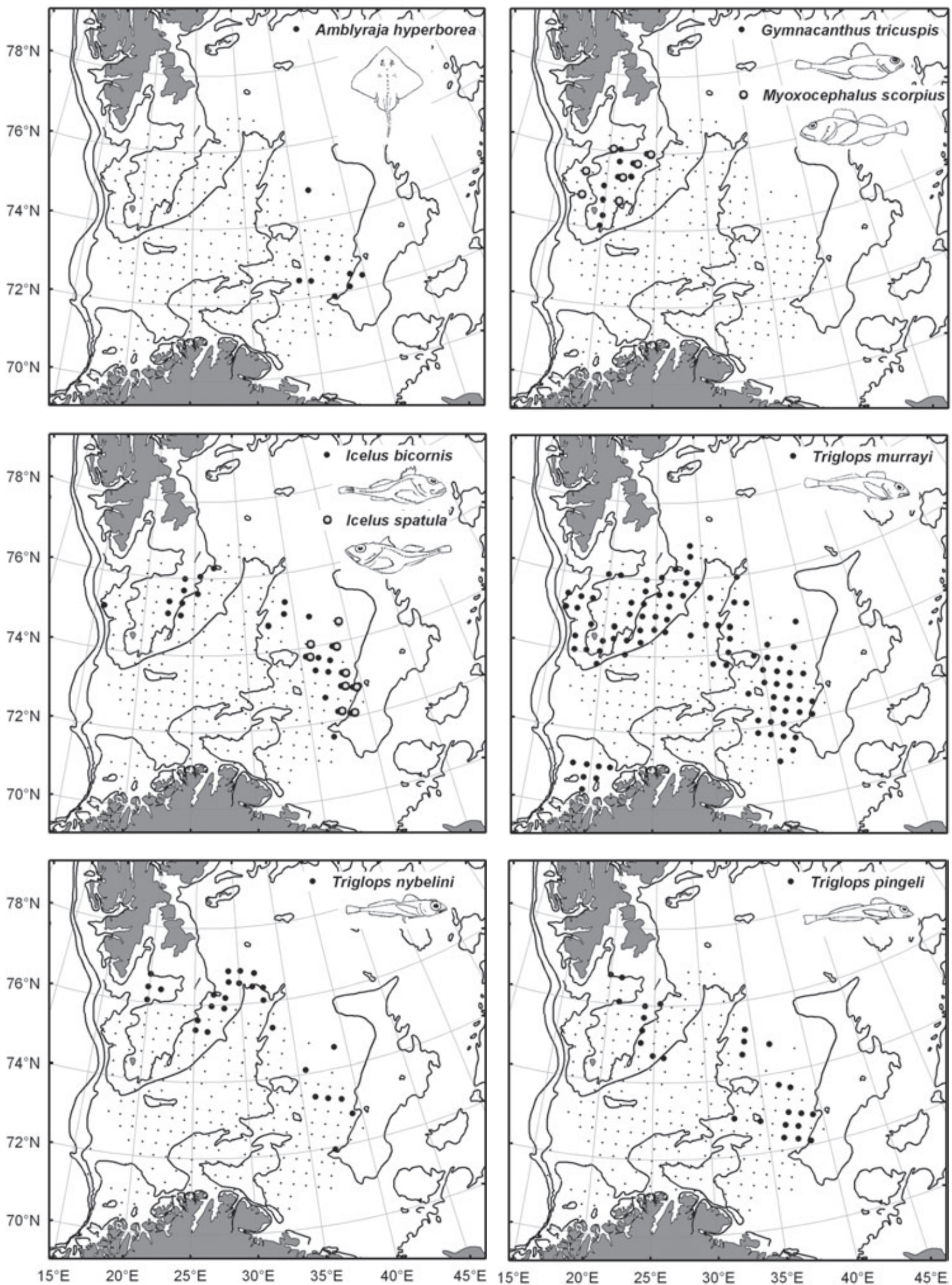

Fig. 5 Fish species with a distribution from the Polar Front and northwards. Large dots and circles indicate trawl stations with positive registrations. Small dots indicate trawl stations with negative registrations. 

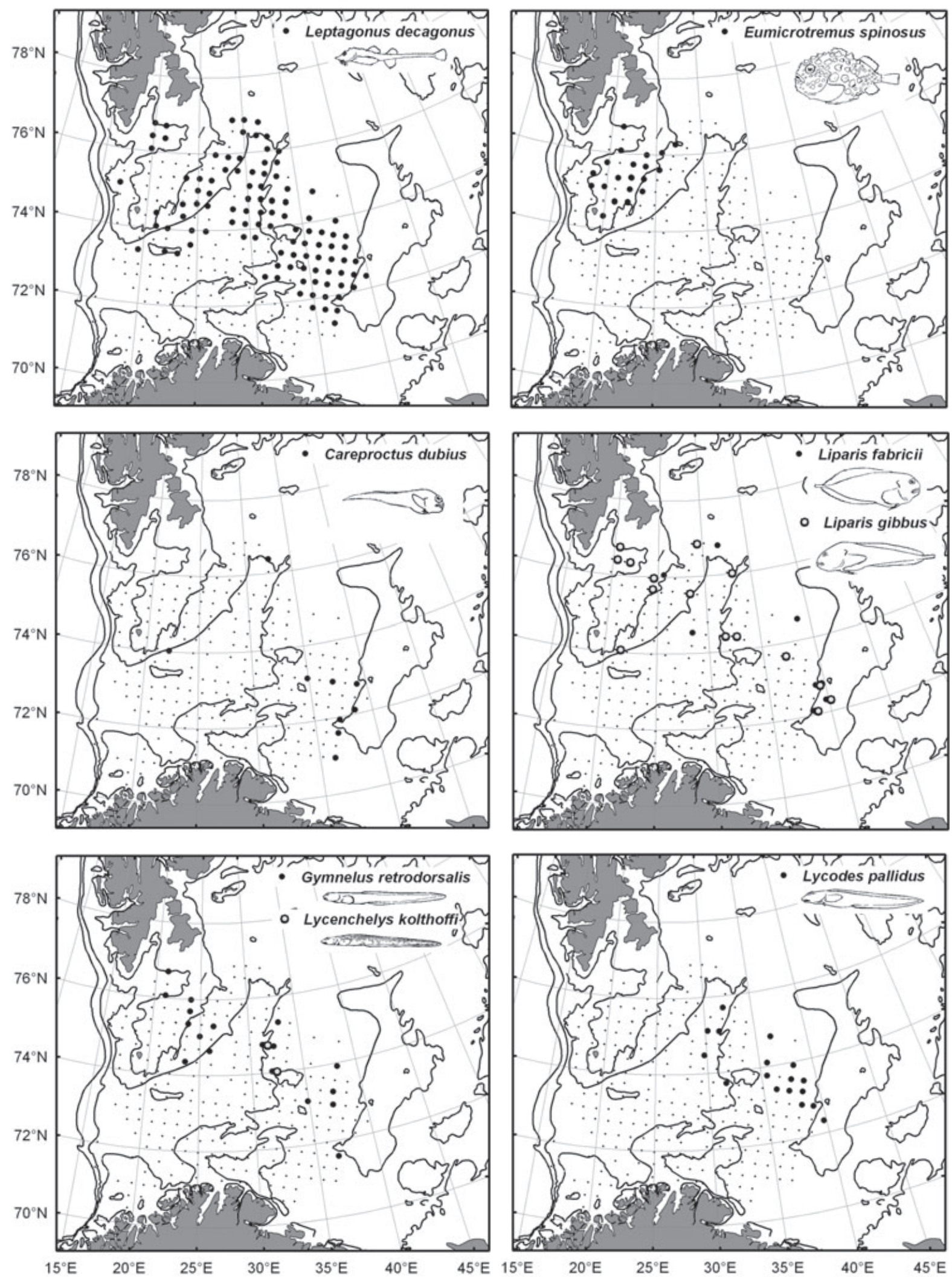

Fig. 5 Continued 

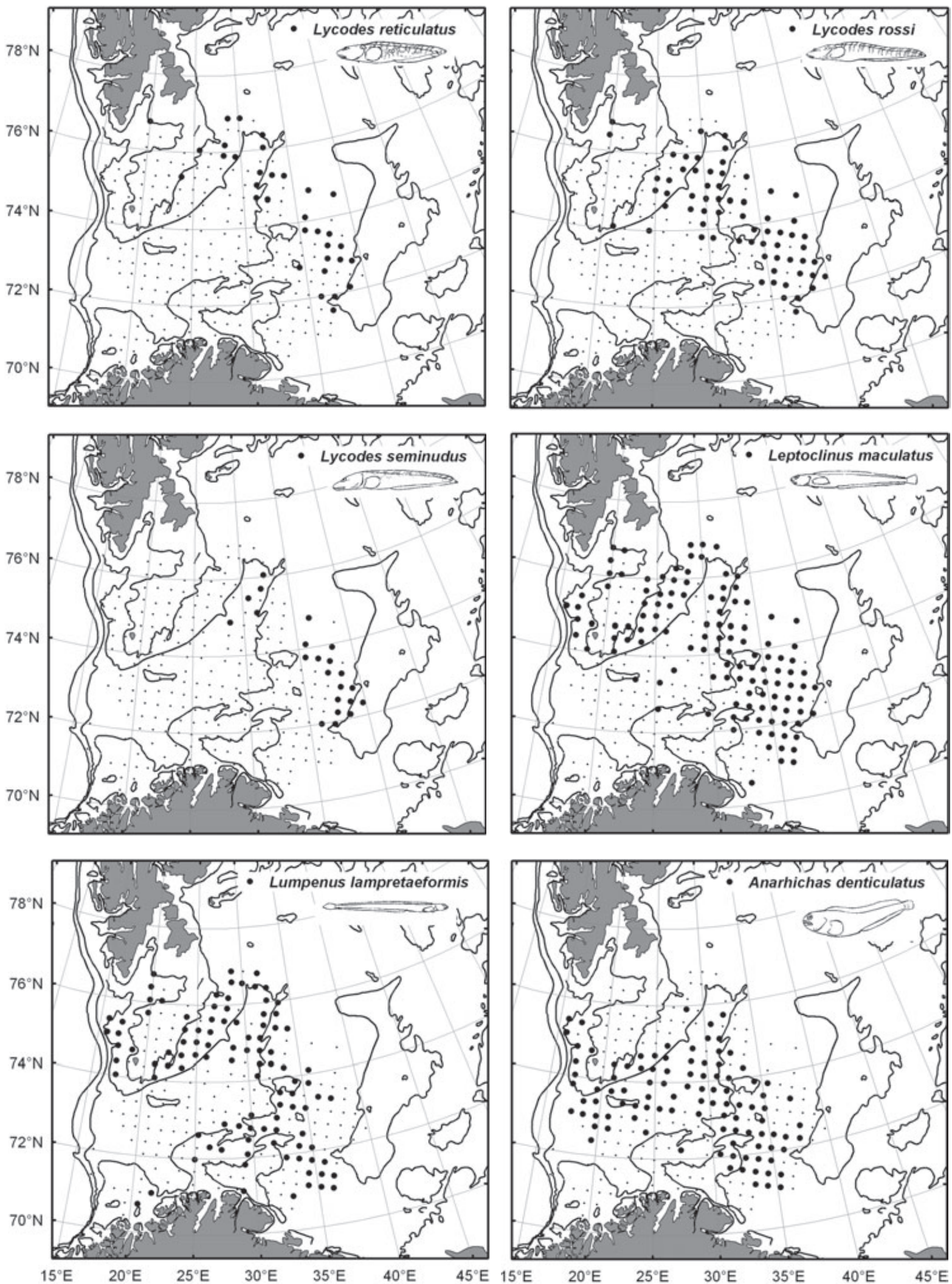

Fig. 5 Continued 
As expected in an ocean area like the Barents Sea, with warmer water from the south meeting cold subzero polar water, the distribution of most of the fish species was associated with temperature. In general, a warm water fish fauna dominated by Gadidae and Scorpaenidae was found to the south of the Polar Front, whereas the true cold water fauna started to appear near the Polar Front and consisted primarily of several species of Cottoidea, Cyclopteroidea, Zoarcidae and Stichaeidae. For more details on the distribution and population changes of the commercially important gadoid and scorpaenoid species, and Reinhardtius hippoglossoides, see Bergstad et al. (1987), Stiansen et al. (2005), Aglen (2006), Hauge (2006), Høines (2006) and Nedreaas (2006).

Many species also showed an association with depth and/or salinity. Studying the variation in salinity in the south-westernmost part of the Barents Sea over a period of 29 years, Ingvaldsen et al. (2006) held that so far no effect on the occurrence of organisms has been found to be related to a recent increase in salinity. Our results indicate that an increased salinity might potentially affect several species, benefiting those that also associate with warmer water, such as Melanogrammus aeglefinus, Sebastes marinus and Anarhichas lupus, but the effect of salinity specifically could be difficult to reveal, as high salinity is typical of inflowing Atlantic water, which is warmer.

The distribution of non-commercial demersal fish has been poorly known in the Barents Sea, as revealed from the discrepancies between the distribution maps shown in the two standard handbooks most often used for the area: Whitehead et al. (1984, 1986a, b) and Pethon (2005). In these, the distribution maps disagree strongly

Table 3 Revision of ranges compared with the most recent handbook maps: (1) Whitehead et al. (1984, 1986a, b) and (2) Pethon (2005). Taxonomic revisions in Liparidae refer to (3) Chernova (1988) and (4) Chernova (2005a, b).

\begin{tabular}{|c|c|}
\hline Species & Revised ranges (references used for comparison are given in parentheses) \\
\hline Bathyraja spinicauda & Reduced in the north and south (1) \\
\hline Amblyraja hyperborea & Reduced in the north, south and west (1); extended to the east (2) \\
\hline Rajella fyllae & Reduced in the north (1) \\
\hline Gadiculus argenteus thori & Extended to the north and east (2) \\
\hline Micromesistius poutassou & Reduced in the north (1) \\
\hline Pollachius virens & Reduced in the north (1) \\
\hline Trisopterus esmarkii & Reduced in the north (1) \\
\hline Brosme brosme & Reduced in the north (1) \\
\hline Molva molva & Reduced in the north (1); extended north and east (2) \\
\hline Molva dypterygia & Reduced in the north (1) \\
\hline Sebastes viviparus & Reduced in the north, extended to the east (1); extended to the north and east (2) \\
\hline Artediellus atlanticus & Extended to the east (1) \\
\hline Gymnocanthus tricuspis & Reduced in the south and east (1)(2) \\
\hline Icelus bicornis & Reduced in the south and west (1)(2) \\
\hline Icelus spatula & Extended to the northwest (1)(2) \\
\hline Myoxocephalus scorpius & Reduced in the south and east (1)(2) \\
\hline Triglops murrayi & Extended to the east (1); reduced in the south (1)(2) \\
\hline Triglops nybelini & Extended to the south (1) \\
\hline Triglops pingeli & Extended to the south (1); reduced to the south and west (2) \\
\hline Leptagonus decagonus & Reduced in the south and southwest (1)(2) \\
\hline Cottunculus microps & Reduced in the south (1)(2) and north (1); extended in the north (2) \\
\hline Eumicrotremus spinosus & Reduced in the south and east (1) \\
\hline Careproctus derjugini & Previously unmapped in the area (4) \\
\hline Careproctus dubius & Previously unmapped in the area (4) \\
\hline Liparis fabricii & Extended to the southeast (1) \\
\hline Liparis gibbus & Previously probably mapped by (1) and (2) as Liparis liparis (3) \\
\hline Gymnelus retrodorsalis & Reduced in the south and west (2) \\
\hline Lycodes eudipleurostictus & Extended to the east (1)(2) and north (2) \\
\hline Lycodes pallidus & Reduced to the south (1)(2) and west (2) \\
\hline Lycodes reticulatus & Reduced in the west (1)(2) and south (2) \\
\hline Lycodes rossi & Reduced in the west and south (2) \\
\hline Lycodes seminudus & Extended to the northwest (1); reduced to the south and west (2) \\
\hline Leptoclinus maculatus & Reduced in the southwest (1) (2); extended from littoral areas (2) \\
\hline Lumpenus lampretaeformis & Reduced in the west (1); extended from littoral areas (2) \\
\hline Anarhichas denticulatus & Reduced in the south (1)(2); extended to the east (2) \\
\hline Anarhichas minor & Extended to the north and east (2) \\
\hline Hippoglossoides platessoides & Extended to the north (2) \\
\hline
\end{tabular}


for seven species in each of the families Gadidae and Zoarcidae, for two species in each of the families Rajidae, Cottidae and Stichaeidae, and for one species within the Macrouridae, Scorpaenidae, Psychrolutidae, Cyclopteridae and Pleuronectidae. Notable, but less dramatic, disagreements are found in the maps of an additional one species of Rajidae and one of Cottidae. Our data show better agreement with the maps of Pethon (2005) than with those of Whitehead et al. (1984, 1986a, b), which is not surprising, considering the time difference between those two sources, and the fact that Pethon's coverage is geographically more restricted than that of Whitehead et al., and therefore gives more detailed and accurate information for the specific area covered. Yet our maps seem to represent a considerable revision of the range in relation to one or both of these two handbooks for the species listed in Table 3. To what extent these differences may be attributed to population changes and/or actual shifts in ranges over the last decades is unknown.

Recent taxonomic revisions (Chernova 1988, 2005a, b) have altered the species composition in the Barents Sea within the family Liparidae from that given by Whitehead et al. (1984, 1986a, b) and Pethon (2005). Liparis liparis (Linnaeus, 1766) was not found in our material, but L. gibbus was. This agrees with the results from Chernova (1988). In her revisions of Careproctus, Chernova (2005a, b) removed C. reinhardti, C. micropus and C. ranula from the species list for the Barents Sea, and instead introduced six species to the Barents Sea-Svalbard area, five of them new to science. Resulting from limited material for each of her species, Chernova was unable to map their distribution. In our material we recorded C. derjugini as the most common and widespread species, and C.dubius as a less common species.

Published maps showing results from trawl stations in the same area as our study are available for Dipturus linteus, Trisopterus esmarkii, Gaidropsarus argentatus, Lycodes gracilis, Cottunculus microps and Triglops murrayi (Dolgov 2000), and they agree well with our maps for these species. These, along with those of Dolgov (2004), constitute a foundation for accurate distribution maps of the demersal fish species in a major part of the Barents SeaSvalbard region. In light of expected climatic changes and increased economic development in the region, this mapping may serve as a basis for future monitoring of important components of the marine ecosystem in this area.

\section{Acknowledgements}

We are very grateful to Gunnar Langhelle, Svend Lemvig and Harald Larsen, for their efforts in collecting and preserving material. Peter Rask Møller kindly revised the identification of a number of the zoarcid specimens. We also thank two anonymous reviewers for comments on the manuscript.

\section{References}

Aglen A. 2006. Nordøstarktisk torsk. (North-east Arctic cod.) Fisken og Havet, særnummer 1, 48-52. (Norwegian with English summary.)

Andriyashev A.P. 1964. Fishes of the northern seas of the U.S.S.R. Jerusalem: Israel Program for Scientific Translations. (Originally published in Russian in 1954.)

Bergstad O.A., Jørgensen T. \& Dragesund O. 1987. Life history and ecology of the gadoid resources of the Barents Sea. Fisheries Research 5, 119-161.

Burgos G.E. 1989. The bottom fish community of the Barents Sea in the winters 1984 to 1987. Master of Philosophy Thesis, University of Bergen.

Chernova N.V. 1988. Fishes of the family Liparididae of the Barents Sea and adjacent waters. I. Species composition of the genus Liparis. Journal of Ichthyology 28, 62-67.

Chernova N.V. 1991. Liparovye ryby evroaziatskoj Arktiki. (Snailfishes [Liparididae] from the Eurasian Arctic.) Apatity: Akademiya Nauk SSSR.

Chernova N.V. 1998. A new species Gymnelus andersoni sp.nova, from the Arctic Seas with refinement of the species status of G. retrodorsalis LeDanois and G. pauciporus Anderson (Fam. Zoarcidae). Journal of Ichthyology 38, 708-715.

Chernova N.V. 2005a. Review of Careproctus (Liparidae) of the North Atlantic and adjacent Arctic, including the generic type C. reinhardti, with rehabilitation of C. gelatinosus (Pallas) from Kamchatka. Journal of Ichthyology 45, S1-S22.

Chernova N.V. 2005b. New species of Careproctus Liparidae from the Barents Sea and adjacent waters. Journal of Ichthyology 45, 689-699.

Chernova N.V. \& Borkin I.V. 1993. Snailfishes (Scorpaeniformes: Liparidae) from areas of Franz Josef Land, to the north of Svalbard and the adjacent continental slope. Norsk Polarinstitutt Meddelelser 126, 21-30.

Dolgov A.V. 2000. New data on composition and distribution of the Barents Sea ichthyofauna. ICES CM 2000 Mini 12, $1-13$.

Dolgov A. 2004. Nepromyslovye ryby i skaty. (Noncommercial fishes and skates.) In M.S. Schevelev (ed.). Issledovaniya PINRO v rajone Arkhipelaga Schpitsbergen. (Investigations by PINRO in the Spitsbergen Archipelago area.) Pp. 229-274. Murmansk: Izdatel'stvo PINRO.

Dolgov A.V. 2006. New data on the distribution of rare and new fish species in Russian waters of the Barents Sea. Journal of Ichthyology 46, 139-147.

Engås A. \& Godø O.R. 1989. Escape of fish under the fishing line of a Norwegian sampling trawl and its influence on survey results. ICES Journal of Marine Science 45, 269-276.

Fossheim M., Nilssen E.M. \& Aschan M. 2006. Fish assemblages in the Barents Sea. Marine Biology Research 2, 260-269.

Hauge K.H. 2006. Nordøstarktisk hyse. (North-east Arctic haddock.) Fisken og Havet, sxrnummer 1, 53-55. (Norwegian with English summary.) 
Hognestad P.T. \& Vader W. 1979. Saltvannsfiskene i NordNorge. (Saltwater fish in northern Norway.) Tromura 6, $1-74$.

Høines Å. 2006. Nordøstarktisk blåkveite. (North-east Arctic Greenland halibut.) Fisken og Havet, sxrnummer 1, 56-58. (Norwegian with English summary.)

Ingvaldsen R., Loeng H., Ådlandsvik B. \& Stiansen J.E. 2006. Abiotiske faktorer. (Abiotic factors.) Fisken og Havet, særnummer 1, 20-23. (Norwegian with English captions to figures and tables.)

Loeng H. 1991. Features of the physical oceanographic conditions of the Barents Sea. Polar Research 10, 5-18.

Nedreaas K. 2006. Vanlig uer og snabeluer. (Golden redfish (Sebastes marinus) and deep-sea redfish [S. mentella].) Fisken og Havet, sxrnummer 1, 59-62. (Norwegian with English summary.)

Pethon P. 1998. Aschehougs store fiskebok-Norges fisker i farger. (Aschehoug's big fish book-Norway's fishes in colour.) Aschehoug, Oslo.

Pethon P. 2005. Aschehougs store fiskebok-Norges fisker $i$ farger. (Aschehoug's big fish book-Norway's fishes in colour.) Aschehoug: Oslo. (Revised version.)
Stiansen J.E., Aglen A., Bogstad B., Budgell P., Dalpadado P., Dolgov A.V., Dommasnes A., Filin A.A., Gjøsæter H., Hauge K.H., Høines Å., Ingvaldsen R., Johannesen E., Jørgensen L.L., Karsakov A.L., Klungsøyr J., Knutsen T., Lien V., Loeng H., Mehl S., Mortensen P.B., Muchina N.V., Nesterova V.N., Olsen E., Orlova E.L., Ozhigin V.K., Pedchenko A.P., Stenevik E.K., Skogen M., Titov O.V., Tjelmeland S., Zabavnikov V.B., Ziryanov S.V., Zhukova N.G., Øien N. \& Aanes S. 2005. Joint PINRO/IMR report on the state of the Barents Sea ecosystem 2005/2006. IMR/PINRO Joint Report Series 3 (2006).

Whitehead P.J.P., Bauchot M.-L., Hureau J.-C., Nielsen J. \& Tortonese E. 1984-1986: Fishes of the north-eastern Atlantic and the Mediterranean. Vol 1. Paris: UNESCO.

Whitehead P.J.P., Bauchot M.-L., Hureau J.-C., Nielsen J. \& Tortonese E. 1986a: Fishes of the north-eastern Atlantic and the Mediterranean. Vol 2. Paris: UNESCO.

Whitehead P.J.P., Bauchot M.-L., Hureau J.-C., Nielsen J. \& Tortonese E. 1986b: Fishes of the north-eastern Atlantic and the Mediterranean. Vol 3. Paris: UNESCO. 